\title{
Unorganized Laborers in Dhanbad -Jharia Coal Mines
}

\author{
${ }^{1}$ Shaswati Mukherjee, ${ }^{2}$ Dr (Prof).S. N. Choudhuri (R\&D) \\ ${ }^{I}$ Department of Economics, CMJ University, India. \\ ${ }^{2}$ AryaBhatta Institute of Engineering and Management Durgapur, India.
}

\begin{abstract}
Coal sector is a giant and huge sector in India's economy which employs thousands and thousands of laborers in this mining sector, but they hide within them al00 years old history of oppression a story that has never been documented or given much importance in independent India. Yet it is this oppression that has led to labor unrest and resulted in some of the gruesome stories between these unorganized laborers and the mine managers. Unlike the organized sector, in this sector we deal with laborers who have not acquired a high profile, tasted the benefits that can be gained from organization or derived the advantages flowing from high visibility. The large portions of labor force working in the coal mines of India plays vital role in any scheme of industrialization and the development of the country in general. India has many coal mines which employs about sixty lakh of unorganized laborers either directly or indirectly. The wages that the unorganized laborers get are meager and this is clearly not enough to satisfy the growing aspirations of a community that is utterly marginalized and feels alienated. It is this socio-economic struggle that goes out of control. At times there are labor troubles in mines.
\end{abstract}

\section{Introduction}

Dhanbad - Jharia coal fields are a rural-industrial area. Debates and research about the formation of the working class tend to focus on urban industries and slum cities while quantitavely at least in the global south, rural industries keep on being an important sphere in the process of proletarianisation. According to the state government, the town of Jharia is to be shifted due to the uncontrollable coal mine fire, which was found to be undousable, leading to loss of property and lives. Coal worth Rs. 60000 crore (US\$12 billion) is lying unmined and the state government feels the shifting will help in exploiting the resources.

There are a number of illegalized mines in the Dhanbad-Jharia coal belt where unorganized workers are under extra pressure of law and mafia-type of middlemen. These illegalized mines have given rise to unorganized sector and thereafter unorganized laborers. A large number of children under the age group of 18 years work in such mines. These mines workers are mostly from Odhisa, West Bengal, Bihar, Chhattisgarh and Assam. These mines laborers are unorganized with no unions representing them, unaware of their rights and privileges. They are only concerned about their day-to-day payments.

The investigation which was carried out showed that the mine laborers here face a number of problems which need to be highlighted:

(1)The mine laborers here do not have any fixed working hours. Because of the absence of fixed working hours the conditions are very deplorable. They are only concerned about their jobs. If they do not work according to the orders of so-called mine managers or middlemen, it may so happen that they may not get work for about 3-4 days as they may be replaced by any other worker.

(2)There is easy entry and exit in the job. As these laborers are unorganized, they do not have the privilege of job security. If they are unsatisfied or want to go back to their villages they can go. If any laborer is ready to work in the mines, they can approach the middlemen and start working in the mines.

(3)There is Lack of security of employment and other social security benefits. The laborers are illiterate and unaware of any labor laws or any social security benefits. They are mainly migrant laborers from adjoining states, desperate to earn some money to fulfill their basic needs. So the question of employment security and other benefits do not arise for them.

(4)There is Lack of support from government. The central and the state government are aware of the plight of these unorganized laborers yet they have been unable to solve their miseries. Moreover any changes in the laws are only in the paper work and kept under the table. The laws are not significantly implied. The deplorable conditions of these mine workers continue.

(5)There is Lack of housing and access to urban services. The mine laborers in these areas live in huts nearby mines so that they can go to work easily. The workers live in slums and squatter areas in and around mines. 
(6)It was also observed during the research work that the mines are like rat-hole10feet by 10 feet and 400 feet deep where a mere slip of foot will plunge one to a certain death. Every five minutes a wooden bucket brimming with coal is heaved out of a burrow. The coal is dumped on the side of the quarry before being loaded on to the waiting truck.

(7) We could see some child laborers who were around 16-17 years of age and working in the mines along with their parents. Everyday a child mines 30-40 buckets of coal from the quarries. Death is inevitable.

(8)The name Dhanbad is synonymous with coal mafia. The mafia is an economical and social network which reaches from money-lending activities, illegal liquor shops, paid goons to illegal mines and transport contract.

(9)The Dhanbad-Jharia region is said to be one of the most polluted areas of the world. Mining itself is a rather forceful intervention in the environment, but capitalist-socialist relations have resulted in forms of mining, which aggravate the attack on nature and as part of it on human bodies.

(10)The productivity drives towards open-cast mining has increased the dust-production, the whole area is covered with fine-coal dust, causing epidemic respiratory suffering.

\section{Research Methodology}

All these problems have been investigated in a number of ways. The investigation was carried out for almost three weeks in Dhanbad-Jharia coal belt. Moving around and having face to face with the coal mining laborers and also the so called laborer supplier (middlemen), we found that these unorganized laborers are backward and discriminated.

These mine laborers are absolutely unaware of the basic laws and benefits. It is hard for these laborers to fulfill even the basic necessities of life. Life is very hard for them. They are exploited. The mines that enters the labor -intensive, low wages and precarious realm where workers are under extra pressure of law and mafiatype of middlemen. Some of the smaller mines mainly the wider rural industry such as brick-kiln industry or their product is sold in local markets. There are a number of illegal mines in Dhanbad- Jharia coal belt which has given rise to unorganized sector and therefore unorganized laborers. A large numbers of children under the age group of 18 years work in such mines. These mine laborers are mostly from the adjoining districts and adjoining states. Having a talk with these laborers we came to know that these laborers are all migrant agricultural laborers, all landless workers with no alternative employment in the villages. They have migrated in the mining areas so that they can earn their livelihood by working in the mines.

As we have found that the mines are extremely dangerous and have no concept of basic safety measures.

Due to mining work, related labor migration starting from the late $19^{\text {th }}$ century, the tribal population became minoritarian and marginalized in the region of South-Bihar- the mine owners replaced the local village workers increasingly with migrant workers.

There are about 115 official coal mines and probably the same amount of unofficial mines. They are India's main centre of coking coal. Going around in the area we have seen vast open-cast mines scattered in the region, interspread with villagers and miners' colonies.

In order to cut cost, many mines-and not only the unofficial mines (even some official mines) are not refilled with sand, once the coal is extracted. This results in gas-accumulation, underground explosion, underground fires and caving in of whole areas. Since years, a large scale underground fire burns under the surface of Jharia, which is the living area of about seven lakh people. Here and there the earth cracks open and therefore gas, flame, and smoke emerge from within.

The industry destroys nature and harms human and creates a different social environment. The mining industry brings together thousands of people from all the adjoining states. They live in village type of environment. The acknowledgement of working class social power is petrified in the miners' statues which can be seen in many squares of Dhanbad area. At the same time, we can the looming nightmare and desolate place of stranded individuals.

Data reveal that mine laborers are mostly illiterate. They do not have basic knowledge of numbers. What they actually earn per day is not the same which is shown in the papers. It is again exploitation. Leave alone basic rights or rules, for them it is only a matter of survival. Earning everyday is their sole motive. If they fail to earn for one day, it is difficult for them to light their kitchen. Such is their deplorable condition that it seems both the mining management and the state government are unaware of this pathetic scene. 


\section{Results} coal mines:

Specifically, we have addressed the following issues of the unorganized laborers in the Dhanbad-Jharia

Nowadays the majority of mining workers are hired through contractor or they work in unofficial mines; and some of them are still referred to as "tribal villages". They lack the infrastructure of colonies. They are even more threatened by displacement, but they are mining villages in the sense that their economic and social daily lives evolves around mines, either by direct employment or direct services.

We have studied from resources that the merger of trade union collaboration and illegalized economic sector created the backbone of Dhanbad mafia .The mafia was instric part of the mining regime during the1970s to 1990s. The specific composition of the (local/migrant) mining work force can partly explain the populist success of the Jharkhand movement, the other main form of class collaboration in the Dhanbad mining area.

While mafia and regionalism controlled the reproduction of the impoverished rural proletariat and the labor intensive mines, Mechanization in the central mines attacked the core work force and at the same time deepened the separation between workers in the centre and the periphery of the mining industry. Sixty percent of the workforces in Bharat Coking Coal Limited (BCCL) are hired through contractors. While permanent workers earn between Rs. 700-Rs. 1000 per day and receive company health care, company accommodation and other benefits, the workers hired through contractors are paid Rs. 100 a day and they receive no extra benefits.

These workers do not belong to any unions. There are often strikes and protest rally by these unorganised laborers demanding the payment of minimum wages and the implementation of other statutory rights.

Scattered in the region are the vast open-cast mines, interspersed with villages and miners colonies. Trucks loaded with coal and heavy machinery dominate the scenery, interspread by push carts and bicycles loaded with coal.

Neither is the social atmosphere polluted by the urban stress and feeling of anonymity. One of the major divisions and tragic separation which capitalist development creates is the division of town and village.

The town offers a breakaway from the misery and cultural oppressiveness of the village, but this urban freedom turns out to be a mirage, hiding stress, lack of breathing space and social coldness. There seems to be no alternative to this quasi-natural dichotomy and the communist trajectory to abolish both village and town seems utopian.

\section{Discussion}

Here we need to know the role of the government and the trade unions to solve the problem of the unorganized laborers in the coal mines of India. Trade Unions are a part of the society and as such have to take into considerations the national integration as well. Some of the responsibilities in the social arena which they can take care of are:

- Promoting and maintaining national integration by reducing the number of industrial disputes.

- Incorporating a sense of corporate social responsibility in workers.

- Achieving industrial peace.

The government should take more responsibilities for the implementation of various laws so that the bargaining power of the unorganized laborers improves. It should also look after the risky working conditions in which these unorganized laborers work and which is a threat to their lives.

The large portion of labor force working in the coal mines of India plays vital role in any scheme of industrialization and the development of the country in general. Modern technologies, increased awareness and Mining Legislation enable coal required by the nation to be mined without destroying the natural environment, retaining the mine area safe for working with lesser harm. Increase in work efficiency depends on a sound industrial environment around mining area. Working in mines involves physical accident and blows, muscular and nervous strain, monotony, noise and workers efficiency largely depends on work zone air quality and ambient air, quality, extended of suspended particular matter (SPM).

Different physical environments, say coolness, heat, dampness and noise also influences the efficiency of labor and can be measured for purpose of correlating conditions and results in output, accidents, lost time and turnovers. Working conditions should be compatible with an employees' physical comfort which contributes to enhance the job satisfaction by maintaining the normal temperature, combating humidity, proper ventilation, illumination, noise at work place. Good and favorable working condition and a congenial working environment make the workers adaptable both physiologically and psychologically.

Long hours of work and poor conditions sap the vitality of workers, render them inefficient making them psychologically unwilling to work. Hence a supportive environment is a prerequisite to keep the physical and mental stress of the workers at its minimum. 
India has a numerous workers' right laws such as those prohibiting discrimination, aim to guarantee fair and human condition of work, those that provide social security, minimum wage, and right to organize and form trade unions and enforce collective bargaining.

In the early 1990 's, it was reported that around $40 \%$ to $50 \%$ of all mining workers in this area were indebted to money lenders who often extorted money on pay-day with the help of upper hierarchy This network reached into the reproduction sphere in the form of gambling dens, illegal distilleries and into the sphere of unofficial mining. The restructuring during the nationalization process opened various gaps between the centralized command and workers reproduction between different groups of workers, between different sectors and departments of the emerging state run economy. The mafia mediated between these gaps both economically-inform of con tractors or managers of illelagalised mines-and politically as part of the trade unions and within the political beauracracy. With the large scale replacement of work force during the first weeks of nationalization the so called ghost workers appeared on the pay roll. People with connections managed to get a salaried job in the coal mines without actually working there.

The existence of a strong and recognized trade union is a pre-requisite to industrial peace. Decisions taken through the process of collective bargaining and negotiations between employer and unions are more influential. Trade unions play an important role and are helpful in effective communication between the workers and the management.

\section{Summary}

The government has shown awareness of the problem of the mine workers to a little extent in practice but there are numerous laws which have been tabled and many of them which have been passed. Even the state government of Jharkhand has some laws for the betterment of the mining workers. Another problem which acts as a hindrance to all these policies is the frequent change in the government. No government has completed its full term for the past few years. The state of Jharkhand was under President Rule for quite along time as a result of which many files were pending. The Central as well as the state government must look into the problems of these unorganized laborers in coal mine seriously. No matter whatever be the problems of implementation of these laws but they must make it a point not to overlook the grave situation in which these workers work. These workers are the backbone of the mining industry. Have we ever imagined the kind of atmosphere in which they work in? Did we ever look into the dingy mining holes in which they work and which makes their life vulnerable to all kinds of life threats. We need to look into all these seriously so that these unorganized laborers can at least look into the brighter sides of life and for their survival. Life for them is not for some fun but for just survival. The government must provide them certain facilities so that their efficiency increases and they can lead a decent standard of living. Child laborers and women laborers should be protected from unfair practices of employment. Most important is that the working conditions in the mines should be looked into urgently and effort must be made so that they can be enrolled into the factory mines directly, if not with a handsome wages but with wages so that they can lead their life in a decent manner.

\section{Acknowledgement}

I would like to express my deepest appreciation to all those who provided me the possibility to complete this report.

First and foremost, I wish to express my gratitude to the supervisor of my research work Dr.(Prof)S.N.Choudhury who was abundantly helpful and offered invaluable assistance, support and guidance.

Deepest gratitude are also due for my husband Mr. Santanu Mukherjee (MBA), PG Diploma (Banking), C.A.I.I.B, without whose knowledge and assistance, this study would not have been successful. He was very helpful during the field work and talking to the workers in the mining areas. Special thanks again go to my husband Mr. Santanu Mukherjee who helped me to assemble the parts and gave suggestion about the field work task.

Also I would like to thank the unorganized mine laborers in my survey work, who have willingly shared their precious time during the process of interviewing.

Last but not the least; I would like to thank Mr. P.Agasthy, the chairman of Arya Bhatta Institute of Engineering and Management who have invested his full effort in guiding, so that the survey work could be completed on time.

I would like to than $\mathrm{k}$ my family members who have supported me throughout the entire process, both by keeping me harmonious and helping me putting pieces together. I will be grateful forever for your love and support. 


\section{References}

[1]. Coal labor in India-A close look

[2]. Coal Mining in India-Sanhati weekly.

[3]. Unorganized Labor Market in India.

[4]. News Today - Dhanbad.

[5]. Indian Labor Law.

[6]. Report of the National Commission on Labor-Chapter seven.

[7]. Labor Rights and Labor Standards for Migrant Labor in India-Dr. W.N.Salve

[8]. Coal Resource of India-Coal Wing, Geological Survey OF India, Kolkata. 